\title{
Characteristics of milk production systems and feed strategies for dairy cows in the North and Northwest of Paraná State
}

\section{Caracterização dos sistemas de produção de leite e estratégias de alimentação de vacas leiteiras nas Regiões Norte e Noroeste do Paraná}

\author{
Milton Takeo Yabe ${ }^{1}$; Ferenc Istvan Bánkuti²*; Julio Cesar Damasceno²; \\ Marcel Moreira de Brito ${ }^{3}$
}

\begin{abstract}
Although milk production is widespread, several barriers remain that limit its competitiveness, including those related to low performance parameters in milk production systems (MPS), which can be minimized through the adoption of effective nutritional strategies. The increased use of corn can provide benefits to both rural production and the entire milk production chain. Moreover, it represents the major economic strategy of adding value to grain produced in Brazil, via the transformation of milk. The objective of this study was to characterize MPS in the north and northwest regions of Paraná, Brazil, and identify the relationship between productive and structural variables across the supply of concentrate containing corn and grain corn for dairy cows. Data were collected from 185 MPS and analyzed via multivariate statistical techniques, including the analysis of hierarchical clusters, as well as hypothesis testing and means comparison using ANOVA. A cluster analysis was performed based on two qualitative and dichotomous variables: (i) concentrate containing corn fed to dairy cows and (ii) grain corn fed to dairy cows. Four groups were defined: Group 1 ( $\mathrm{N}=99$ MPS) was characterized by systems where cows were fed corn only in the form of a concentrate, referred to as "Concentrate"; Group 2 ( $\mathrm{N}=41 \mathrm{MPS}$ ) where cows were fed corn incorporated in both concentrate and grain form, referred to as "Concentrate + Grain"; Group 3 (N = 14 MPS), where corn was supplied to cows solely in the form of grain, referred to as "Corn Grain"; and finally, Group 4 (N=41 MPS), which included systems where no corn was supplied to cows, referred to as "Zero Corn." When weighed against the productive and structural variables, Groups 1 and 2 did not differ significantly $(\mathrm{P}>0.05)$, nor did Groups 3 and $4(\mathrm{P}>0.05)$. However, Groups 1 and 2 were significantly different from Groups 3 and 4 $(\mathrm{P}<0.05)$. These results suggest that the strategy of supplying corn either exclusively as concentrate or in combination with grain corn resulted in better responses to the structural and productive variables analyzed in the MPS. Our results indicate that this is an important strategy for aggregation of grain value via transformation of milk. In addition, no difference was noted between exclusive use of grain corn and non-use of corn.
\end{abstract}

Key words: Animal feeding, concentrate, corn, milk production, multivariate analysis

\footnotetext{
${ }^{1}$ M.e, Zootecnia, Programa de Pós-Graduação em Zootecnia, Universidade Estadual de Maringá, UEM, Maringá, PR, Brasil. E-mail: miltontakeo@hotmail.com

2 Profs., Departamento de Zootecnia, Universidade Estadual de Maringá, UEM, Maringá, PR, Brasil. E-mail: ferencistvan@gmail. com; jcdamasceno1@gmail.com

${ }^{3}$ Prof., Centro de Ciências Agrárias, Universidade Estadual do Oeste do Paraná, UNIOESTE, Marechal Cândido Rondon, PR, Brasil. E-mail: marcelmbrito@gmail.com

* Author for correspondence
} 


\section{Resumo}

A cadeia produtiva do leite possui grande representatividade. Entretanto, há ainda um conjunto de entraves ao aumento de sua competitividade, entre esses, aqueles relacionados aos baixos índices zootécnicos nos Sistemas de Produção de Leite (SPL), que podem ser minimizados com estratégias nutricionais. O maior emprego do milho poderá trazer benefícios para a produção rural e para toda a cadeia produtiva do leite. Além disso, representará uma importante estratégia econômica de agregação de valor ao grão produzido no Brasil, via transformação deste em leite. O objetivo proposto foi caracterizar SPL nas Regiões Norte e Nordeste do Paraná e identificar a relação entre variáveis produtivas e estruturais frente a oferta de concentrado contendo milho e de milho em grão para vacas leiteiras. Foram coletados dados de 185 SPL, analisados a partir de técnicas de estatística multivariada, entre essas, a análise de clusters hierárquicos. Foram também utilizados teste de hipóteses e comparação entre médias (Anova). A análise de clusters, foi realizada a partir de duas variáveis qualitativas e dicotômicas: (i) utilização de concentrado contendo milho na alimentação de vacas leiteiras e (ii) utilização de milho em grão na alimentação de vacas leiteiras. Quatro Grupos foram definidos. O Grupo 1 (N=99 SPL) foi caracterizado por ofertar o milho somente na forma de concentrado, sendo denominado por "Concentrado". O Grupo 2 (N=41 SPL) foi caracterizado por ofertar milho incorporado ao concentrado e também milho em grão. Sendo este denominado como "Concentrado + Grão". No Grupo 3 (N=14 SPL) a oferta de milho ocorre somente na forma de grão e, portanto, foi denominado de "Grão". O Grupo 4 (N=41 SPL), foi representado por sistemas em que a não há oferta de milho aos animais, sendo este denominado por "Zero Milho". Quando analisados frente as variáveis produtivas e estruturais, os Grupos 1 e 2 não diferiram ( $P>0,05)$. Assim como não foram constatadas diferenças entre os Grupos 3 e 4 ( $\mathrm{P}>0,05)$. Entretanto, os Grupos 1 e 2 se distinguiram dos Grupos 3 e $4(\mathrm{P}<0,05)$. Os resultados indicaram que a estratégia de oferta exclusiva de milho incorporado ao concentrado ou deste, em conjunto com o milho em grão resultaram em melhores respostas para variáveis estruturais e produtivas nos SPL analisados. Esse resultado indica, ser esta uma importante estratégia para agregação de valor ao grão, via transformação deste em leite. Além disso, que a utilização exclusiva do milho em grão ou a sua não utilização não foram diferentes.

Palavras-chave: Alimentação animal, análise multivariada, milho, concentrado, produção de leite

\section{Introduction}

Milk production is of great social and economic importance in Brazil. In 2013, 32.3 billion liters of milk were produced in the country, making Brazil the world's fourth largest producer of milk (FAO, 2013). The State of Paraná, the region of focus for this study, is the third largest state in Brazil in terms of production volume, with 3.9 million liters of milk produced from 1.6 million dairy cows in 2012 (IBGE, 2012). Socially, the importance of this activity is reflected in the large number-114,000 of farms dedicated to dairy production in Paraná, of which $85.1 \%$ rely on family labor, with an average of 2.4 family members employed in dairy farming in each of these operations (IPARDES; EMATER, 2009).

Over the past several years, the milk production chain in Brazil has undergone significant economic and political changes (CARVALHO, 2010; BÁNKUTI; BÁNKUTI, 2012) that have favored the maturation of its agents. In addition, studies have shown changes in the volume of milk produced, profile of the MPS, number of small producers, development of performance parameters, and product marketing profile (DAMASCENO et al., 2008). Even with these changes, the production system faces challenges to its growth. The milk produced is considered to be of low quality (SILVA et al., 2011; YAMAZI et al., 2010) and there is room for the improvement of zootechnical indices, such as productivity per animal, stocking rates, and period between births, among others. According to data obtained from SEAB/DERAL (2013), dairy production systems in Paraná are dominated by cows crossbred from two main races, the Holstein and Jersey, although Brown Swiss and Girolando are also present. In these systems, average productivity 
in 2014 was $6.3 \mathrm{~kg}$ of milk per cow daily (INFORMA ECONOMICS - ANUALPEC, 2014).

The poor performance of dairy cows in Paraná is in part because of improper nutrition and inadequate management (SEAB/DERAL, 2013; ARAGÃO; PAES, 2008). According to data taken from SEAB/ DERAL (2013), although 90\% of MPS supplement silage, meal, and feed, this is not sufficient when considering the quantity and quality of the diet of dairy cows.

Productivity, thus, could be enhanced by changing the nutritional management of dairy cows (SIMÕES; OLIVEIRA, 2010). Roehsig (2006), for instance, by discussing the necessity of providing adequate diet quality and quantity, while Colavite et al. (2010), Simões and Oliveira (2010), and Silva et al. (2008) point out that improvement in dairy productivity requires, among other things, appropriate nutritional strategies for dairy cows. In this context, corn supplementation may represent a potential means of increasing productivity. Grain corn is composed primarily of carbohydrates and lipids (PAES, 2006), and thus, may provide a source of additional energy (BUTOLO, 2010). The use of grain corn also facilitates the adjustment of the dietary energy supply, given the nutritional demand of dairy cows. In addition, corn is readily available and inexpensive; according to FAO (2014), corn is the topmost grain produced in the world, with a projected 996 million tons to be harvested in 2014/2015. In Brazil alone, 72 million tons of corn was grown in 2013/2014 (INFORMA ECONOMICS - AGRIANUAL, 2014), with 16.2 million tons (IBGE, 2012) harvested in Paraná and 4.2 million tons destined for export (SEAB/ DERAL, 2013).

Corn is the basis of many types of feed. The proportion of cereal composition in feed formulation intended for dairy farming varies between 23\% and 31\% (ABIMILHO cited in GREGORI, 2012; SINDIRAÇÕES, 2012), which allows for leeway in cereal inclusion. In developed countries, corn may compose up to $85 \%$ of feed (PAES, 2006).

According to Gregori (2012), the use of concentrated feed has become common practice in dairy farms throughout Brazil; up to $60 \%$ of Brazilian farms rely on concentrated feed. Incorporating corn into the concentrate is a strategy designed to increase milk production and to improve the reproductive condition of females. According to Silva et al. (2009), concentrated feed marginally increases production; however, Lana (2007), showed that the use of concentrated feed raises the productive response and Vargas et al. (2013) demonstrated that concentrated feed increased consumption of both dry matter and organic matter.

Bargo et al. (2003) noted that the inclusion of corn in the concentrate resulted in (i) increased milk production per cow; (ii) increased milk production per unit area; (iii) increased stocking rate on pastures; (iv) increased body condition score; (v) increased lactation; and (vi) increased protein content in the milk. Carvalho et al. (2009) found that there is a direct relationship between the use of concentrate for dairy cows and improvement in production rates and technological advances.

Increasing the use of corn in the diet of dairy cows can enhance performance parameters in MPS, benefiting both rural production and the entire production chain. Moreover, it increases the domestic market for corn grain produced in Brazil, an important consideration for the economies of corn-growing regions such as Paraná State. This provides added incentive for field maintenance and increased milk production in the country, both of which will result in higher incomes for farmers and others.

Given the above, the objective of this study was to characterize the MPS in the north and northwest areas of Paraná State and to identify the relationship between productive and structural variables and the supply of concentrate containing corn and grain corn for dairy cows. 


\section{Material and Methods}

Semi-structured formulations were developed and applied (FODDY, 1994) in 185 MPS in 17 municipalities in north and northwest Paraná, which, according to Agricultural Census data (IBGE, 2006), contain a total of 1736 MPS. Snowball sampling (SCHLECHT; SPILLER, 2012; GUPTILL, 2009; PENROD et al., 2003) was used. This procedure does not presuppose the extrapolation of results, but the inference patterns for individuals or groups analyzed (GUPTILL, 2009).

The formulations were composed of two groups of variables, one relating to the use of corn as a supplement to dairy cow feed and the second comprising metric variables characterizing the structure and productivity in the analyzed MPS.

These variables were analyzed using the Statistical Package for Social Science software (SPSS) version 18. Multivariate statistics, specifically a hierarchical agglomerative cluster approach, were used to analyze the data. In this approach, the first individual represents a cluster, with individuals grouped according to the similarity among them (FÁVERO et al., 2009). This analysis results in the formation of distinct groups, but with a high degree of similarity within each group (FÁVERO et al., 2009), with the criterion of general similarity used to define the group number. The formation of these groups was based on two independent variables related to the use of corn in dairy cows: (i) use of concentrate containing corn and (ii) use of grain corn. Both variables were qualitative, with dichotomous yes and no responses. Next, hypothesis testing between the groups and the related variables that defined them was undertaken, using cross-tables. From this, it was possible to characterize groups according to frequency of the use of grain corn and corn incorporated into the concentrate in the diet of dairy cattle.

Following this analysis, new test hypotheses and means comparison (ANOVA) between the groups and the structural and productive variables of MPS were generated, composed of the following: (i) total area of the property (ha); (ii) area set aside for the production of forage (ha); (iii) total milk production ( $\mathrm{kg}$ of milk per day); (iv) total number of dairy cows (heads); (v) number of dairy cows (heads) and (vi) animal production (kg of milk per animal per day). All of these were metric variables. Applying these procedures enabled us to identify correlations between different corn use strategies for feeding dairy cattle, as well as the structural and productive responses. We used Tukey's test at the 0.05 significance level to evaluate equality.

Table 1 shows the variables used in the analysis, their ratings, and the statistical procedures.

Table 1. Variables used in the statistical analysis.

\begin{tabular}{|c|c|c|c|}
\hline Variables & Classification & Used for & $\begin{array}{l}\text { Statistical } \\
\text { procedure }\end{array}$ \\
\hline Use of concentration for dairy cow feed & $\begin{array}{l}\text { Dichotomous } \\
\text { (yes or no) }\end{array}$ & \multirow{2}{*}{$\begin{array}{l}\text { Definition of groups } \\
\text { according to corn use } \\
\text { strategy }\end{array}$} & \multirow{2}{*}{$\begin{array}{l}\text { Hierarchical } \\
\text { cluster analysis }\end{array}$} \\
\hline Use of grain corn for dairy cow feed & $\begin{array}{l}\text { Dichotomous } \\
\text { (yes or no) }\end{array}$ & & \\
\hline Area of the property (ha) & Metrics & \multirow{6}{*}{$\begin{array}{l}\text { Identification of } \\
\text { correlations between } \\
\text { characteristics of MPS } \\
\text { and strategies for } \\
\text { corn use }\end{array}$} & \multirow{6}{*}{ Cross tabs } \\
\hline Area for forage production (ha) & Metrics & & \\
\hline Milk production ( $\mathrm{kg}$ milk day $\left.{ }^{-1}\right)$ & Metrics & & \\
\hline Number of cows (head) & Metrics & & \\
\hline Number of cows in lactation (head) & Metrics & & \\
\hline Animal production (kg of milk per animal per day) & Metrics & & \\
\hline
\end{tabular}




\section{Results and Discussion}

Cluster analysis generated from the independent variables (use of concentrate containing corn and use of grain corn) defined four distinct groups: Group 1 consisted of 99 (53.5\%) MPS; Group 2 of 41 (22.2\%) MPS; Group 3 of 14 (7.6\%) MPS; and Group 4 of 31 (16.7\%) MPS (Table 2).

Table 2. Groups of milk production systems (MPS) constructed from the variables related to the use of grain corn and corn incorporated into the concentrate.

\begin{tabular}{lcc}
\hline \multicolumn{1}{c}{ Groups } & Cases $(\mathrm{N})$ & Percent $(\%)$ \\
\hline Group 1 & 99 & 53.5 \\
Group 2 & 41 & 22.2 \\
Group 3 & 14 & 7.6 \\
Group 4 & 31 & 16.7 \\
Total & 185 & 100 \\
\hline
\end{tabular}

Group 1 was represented by MPS that fed corn to dairy cattle exclusively via incorporation into the concentrate, and thus this group was referred to as "Concentrate" (i.e., Group 1 = concentrate). Group 2 included MPS that provided corn both in concentrate and in grain form, and thus, this group was referred to as "Concentrate + Grain" (i.e., Group 2 = Concentrate + Grain). Group 3 included MPS that provided corn to dairy cows solely in the form of grain corn, and thus, this group was referred to as "Grain Corn" (i.e., Group 3 = Grain Corn). Finally, Group 4 consisted of MPS that did not provide corn to dairy cows, and thus, was termed as "Zero Corn" (i.e., Group 4 = Zero Corn). These data are presented in Table 3.

Groups 1 (Concentrate) and 2 (Concentrate + Grain) together represent $75.7 \%$ of the MPS analyzed (Table 3), indicating that this is an important feed strategy for dairy cows among our sample farms, and is considerably higher than the average percentage for Paraná as a whole (17\% of MPS) (IPARDES; EMATER, 2009). The MPS that composed Groups 2 (Concentrate + Grain) and 3 (Grain Corn) represented $29.7 \%$ of the total MPS analyzed, indicating that relatively few farms made use of grain corn for feeding dairy cattle (Table 3 ).

Grain corn was not used in any (100\%) of the MPS included in Groups 1 (Concentrate) and 4 (Zero Corn); thus, there were no significant differences ( $\mathrm{P}$ $>0.05$ ) between them. For Groups 2 (Concentrate + Grain) and 3 (Grain Corn), grain corn was fed to dairy cows in all of the MPS, resulting in no significant difference between them $(\mathrm{P}<0.05)$, but they were significantly different from Groups 1 and $4(\mathrm{P}<0.05)$ (Table 3). Because grain corn is composed mainly of carbohydrates and lipids (PAES, 2006), it is an important source of energy when added to feed (BUTOLO, 2010). According to Valadares Filho (2006), this grain has $82.4 \%$ carbohydrate and $54.5 \%$ starch. Thus, the supply of grain corn to dairy cattle permits adjustments to be made to the animals dietary energy supply.

Table 3. Percentage of corn incorporated into the concentrate and grain corn in the Groups of milk production systems (MPS) analyzed.

\begin{tabular}{lccccc}
\hline & \multicolumn{4}{c}{ Percentage of corn utilization by each Group } & \multirow{2}{*}{ Total } \\
\cline { 2 - 4 } \multicolumn{1}{c}{ Variables } & 1 & 2 & 3 & 4 & \\
\hline Corn incorporated into concentrate & $(\mathrm{C})$ & $(\mathrm{C}+\mathrm{G})$ & $(\mathrm{GC})$ & $(\mathrm{ZC})$ & \\
Grain corn & $100^{\mathrm{a}}$ & $100^{\mathrm{a}}$ & $0^{\mathrm{b}}$ & $0^{\mathrm{b}}$ & 75.7 \\
\hline
\end{tabular}

$\mathrm{C}=$ Concentrate $\mathrm{C}+\mathrm{G}=$ Concentrate + Grain; $\mathrm{GC}=$ Grain Corn; $\mathrm{ZC}=$ Zero Corn .

Proportions in the same row followed by the same letter do not differ (Tukey's test at $5 \%$ probability). 
The scientific literature indicates that many factors explain the variability among food supply practices in MPS, including those relating to the characteristics of the breed of cows, size of the farm, financial investment capacity, and access to technical assistance. Carvalho et al. (2009) found that increasing use of concentrate in MPS improved milk production by $34.3 \%$. According to the authors, productive systems were those that featured characteristics such as (i) more specialized herd; (ii) larger total area and more land dedicated to milk production; (iii) increase in per-day milk production; (iv) higher number of dairy cows; (v) increase in milk production per animal; and (vi) reduced total herd of cows across the MPS that do not use concentrate for feeding dairy cows.

The analysis of structural and productive responses indicated the predominance $(76.8 \%)$ of crossbred animals in the MPS analyzed (Table 4); this percentage is similar to that $(81.9 \%)$ reported by IPARDES and EMATER (2009) for the same region. Among the identified crossbred animals, crosses of Holstein, Jersey, and Gir predominated.

In Group 1 (Concentrate), crossbred animals accounted for $83.8 \%$ of the herd. For Group 2 (Concentrate + Grain), this percentage was $73.2 \%$, and for Groups 3 (Grain Corn) and 4 (Zero Corn), crossbreds accounted for $57.1 \%$ and $67.7 \%$, respectively. Unknown or undefined breeds made up the second largest share (16.2\%) among the MSPs, while purebreds composed a smaller proportion $(7.0 \%)$ (Table 4).

Purebred individuals were found more frequently in Group 3 (Grain Corn), comprising 21.4\% of all animals, and Group 2 (Concentrate + Grain), comprising $12.2 \%$ of all animals. The lowest percentage of purebred animals $(3.2 \%)$ was found in Group 4 (Zero Corn). In Group 1 (Concentrate), purebreds accounted for $4.0 \%$ of the total number of animals (Table 4). Among the purebreds identified were Holstein, Jersey, and Gir.

The predominance of crossbred and undefinedbreed animals demonstrates the low degree of specialization in milk production between the surveyed samples. According to Nascimento and Bosco (2001), genetics has a direct influence on the production rate and quality of milk, with the highest production rates among purebred animals. Among the evaluated groups in our study, no significant difference $(\mathrm{P}>0.05)$ was noted for genetic patterns (Table 4), suggesting no correlation between cornuse strategy and the genetic patterns of the dairy herds in the MPS that we analyzed.

Table 4. Genetic composition of dairy cows in the analyzed Groups.

\begin{tabular}{lccccc}
\hline \multirow{2}{*}{ Genetic pattern } & \multicolumn{3}{c}{ Percentage of genetic pattern for each Group } & \multirow{2}{*}{ Total } \\
\cline { 2 - 5 } & 1 & 2 & 3 & 4 & \\
\hline Undefined breed & $(\mathrm{C})$ & $(\mathrm{C}+\mathrm{G})$ & $(\mathrm{GC})$ & $(\mathrm{ZC})$ & \\
Crossbreds* & $12.1^{\mathrm{a}}$ & $14.6^{\mathrm{a}}$ & $21.4^{\mathrm{a}}$ & $29.0 \mathrm{a}$ & 16.2 \\
Purebreds** & $83.8^{\mathrm{a}}$ & $73.2^{\mathrm{a}}$ & $57.1^{\mathrm{a}}$ & $67.7^{\mathrm{a}}$ & 76.8 \\
Total & $4.0^{\mathrm{a}}$ & $12.2^{\mathrm{a}}$ & $21.4^{\mathrm{a}}$ & $3.2^{\mathrm{a}}$ & 7.0 \\
\hline
\end{tabular}

$\mathrm{C}=$ Concentrate $\mathrm{C}+\mathrm{G}=$ Concentrate + Grain; $\mathrm{GC}=$ Grain Corn; $\mathrm{ZC}=$ Zero Corn.

* Crossbreds are crosses of Holstein, Jersey, and Gir.

** Purebreds identified are Holstein, Jersey, and Gir

Proportions in the same row followed by the same letter do not differ (Tukey's test at $5 \%$ probability). 
The average size of the properties included in the four groups was 29.6 ha; within individual groups, average farm size was 37.2 ha in Group 2 (Concentrate + Grain), 31.9 ha in Group 1 (Concentrate), 28.3 ha in Group 4 (Zero Corn), and 20.7 ha in Group 3 (Grain Corn). No significant difference $(\mathrm{P}>0.05)$ was detected among the four groups for the variable "property area" (Table 5).

The average area of forage production among all of the MPS analyzed was 5.69 ha. Area for forage production was the highest in Group 1 (Concentrate), averaging 10.7 ha, followed by Group 2 (Concentrate + Grain) at 5.3 ha, Group 4 (Corn Zero) at 3.8 ha, and Group 3 (Grain Corn) at 2.9 ha (Table 5 ). Greater availability of forage production area implies less production risk; moreover, according to Reis et al. (2001), larger areas for forage production correlated with decrease in production cost, because the cost of feed constitutes a large proportion of the total cost of milk production. We detected no significant difference $(\mathrm{P}>0.05)$ among the groups for the variable "forage area" (Table 5), indicating no correlation between the strategy of corn use and size of the forage area in the MPS included in our analysis.

Average milk production in the MPS we analyzed was $142.55 \mathrm{~kg}$ per day. Production was the highest in MPS in Group 2 (Concentrate + Grain), at $251.9 \mathrm{~kg}$ of milk per day, followed by Group 1 (Concentrate) at $183.2 \mathrm{~kg}$ of milk per day, Group 4 (Zero Corn) at $79.65 \mathrm{~kg}$ of milk per day, and Group 3 (Grain Corn) at $55.43 \mathrm{~kg}$ of milk per day. No significant difference $(\mathrm{P}>0.05)$ was detected for this variable between Groups 1 and 2, but a significant difference $(\mathrm{P}<0.05)$ was observed between Groups 3 and 4, as well as between Groups 1 and 2 and Groups 3 and 4 (Table 5). This result is similar to that of several other studies, including Cardoso et al. (2009), Deresz et al. (2003), Martins et al. (2013), and Rennó et al. (2008), all of which showed that milk production increased when concentrate containing corn is used as feed for dairy cows.
Among the analyzed MPS, the average number of dairy cows was 16 . We detected no significant difference $(\mathrm{P}>0.05)$ between Group 1 (Concentrate), with an average of 18 head of cattle, and Group 2 (Concentrate + Grain), averaging 24 head, for this variable, nor between Group 3 (Grain Corn), averaging 10 head, and Group 4 (Zero Corn), averaging 11 heads $(\mathrm{P}>0.05)$. However, significant differences $(\mathrm{P}<0.05)$ were noted between the MPS of Groups 1 and 2, which used concentrate as feed for their dairy herds, and Groups 3 and 4, which did not use concentrate as feed (Table 5). According to Oliveira and Pereira (2009), milk production is strongly influenced by nutrition levels and feed practices, and feed concentrate is one of the inputs with the greatest potential to stimulate milk production primarily due to the increased availability of potentially digestible nutrients that concentrate offers.

Average daily milk production in the MPS we analyzed was $8.3 \mathrm{~kg}$ per head per day. No significant difference $(\mathrm{P}>0.05)$ was detected between Group 1 (Concentrate), the MPS of which averaged $10.0 \mathrm{~kg}$ of milk per head per day, and the MPS in Group 2 (Concentrate + Grain), which averaged $10.3 \mathrm{~kg}$ of milk per head per day. Similarly, no difference $(\mathrm{P}>$ 0.05) was found between the MPS of Group 3 (Grain Corn), which averaged $5.6 \mathrm{~kg}$ of milk per head per day, and Group 4 (Zero Corn), which averaged 7.5 $\mathrm{kg}$ of milk per head per day. However, the latter two groups (Groups 3 and 4) had significantly lower yields $(\mathrm{P}<0.05)$ than did Groups 1 and 2, both of which used concentrate to feed dairy cattle (Table 5). This is in line with the findings of Alvim et al. (1999), who concluded that, for medium and large producers, the supply of concentrate as feed is essential for increased productivity.

There were, on average, 27 head of dairy cows among the MPS included in our analysis. No statistical difference $(\mathrm{P}>0.05)$ was detected between Group 1 (Concentrate), with an average herd size of 29 head among its MPS, and Group 2 
(Concentrate + Corn), with an average herd size of 39 head, nor was there any significant difference between Group 3 (Grain Corn), with an average herd size of 18 head, and Group 4 (Zero Corn), with an average herd size of 21 head $(\mathrm{P}>0.05)$. However, Group 2 (Concentrate + Grain) was found to be significantly different from Groups 3 and 4 (Table 5).

Table 5. Medium values for the typology of Groups analyzed.

\begin{tabular}{lccccc}
\hline \multirow{2}{*}{\multicolumn{1}{c}{ Variables }} & \multicolumn{3}{c}{ Medium values for each Group } & \multirow{2}{*}{$\begin{array}{c}\text { General } \\
\text { average }\end{array}$} \\
\cline { 2 - 5 } & 1 & 2 & 3 & 4 & \\
\hline Area (ha) & $31.92^{\mathrm{a}}$ & $37.32^{\mathrm{a}}$ & $20.79^{\mathrm{a}}$ & $28.35^{\mathrm{a}}$ & 29.6 \\
Forage area (ha) & $10.7^{\mathrm{a}}$ & $5.33^{\mathrm{a}}$ & $2.93^{\mathrm{a}}$ & $3.79^{\mathrm{a}}$ & 5.69 \\
Production (kg day $\left.{ }^{-1}\right)$ & $183.2^{\mathrm{ab}}$ & $251.9^{\mathrm{a}}$ & $55.43^{\mathrm{b}}$ & $79.65^{\mathrm{c}}$ & 142.55 \\
Number of cows in lactation (head) & $18^{\mathrm{ab}}$ & $24^{\mathrm{a}}$ & $10^{\mathrm{b}}$ & $11^{\mathrm{b}}$ & 15.75 \\
Animal production (kg of milk per animal day $\left.{ }^{-1}\right)$ & $10.04^{\mathrm{a}}$ & $10.28^{\mathrm{a}}$ & $5.58^{\mathrm{b}}$ & $7.48^{\mathrm{b}}$ & 8.3 \\
Total number of cows & $29^{\mathrm{ab}}$ & $39^{\mathrm{a}}$ & $18^{\mathrm{b}}$ & $21^{\mathrm{b}}$ & 26.75 \\
\hline
\end{tabular}

$\mathrm{C}=$ Concentrate $\mathrm{C}+\mathrm{G}=$ Concentrate + Grain; $\mathrm{GC}=$ Grain Corn; $\mathrm{ZC}=$ Zero Corn.

Averages in the same row followed by the same letter do not differ (Tukey's test at $5 \%$ probability).

These results demonstrate that the use of concentrate invokes different responses $(\mathrm{P}<0.05)$ for the chosen set of variables compared with MPS that do not use concentrate as cattle feed. Groups 1 (Concentrate) and 2 (Grain + Concentrate) differed $(\mathrm{P}<0.05)$ from Groups 3 (Grain Corn) and 4 (Zero Corn) for the variables (i) "milk production"; (ii) "number of dairy cows"; (iii) "production per animal"; and (iv) "total cow herd." However, no differences were observed $(\mathrm{P}>0.05)$ between MPS that used concentrate exclusively (Group 1, Concentrate) or those that used a mix of concentrate and grain corn (Group 2, Concentrate + Grain). Among the MPS that used grain corn exclusively (Group 3, Grain Corn) and the MPS that did not supply corn to cows in any form (Group 4, Zero Corn), the best result for the variable "milk production" was found in Group 4.

\section{Conclusion}

Our results suggest that the inclusion of corn in the feed of dairy cows, whether incorporated into the concentrate (Group 1, Concentrate) or through the combination of concentrate and grain corn (Group 2, Concentrate + Grain), improved the structural and productive responses in the MPS included in this study. These results indicate that the addition of corn to the feed of dairy cows is an important strategy for enhancing milk production. In addition, the strategies of using grain corn exclusively (Group 3, Grain Corn) and non-use (Group 4, Zero Corn) did not result in different responses in the structural and productive variables analyzed in this study.

\section{Acknowledgments}

We would like to thank the milk producers who participated in this research, the Program of Graduate Studies in Animal Science at the State University of Maringa for enabling the realization of this research, and the Paraná Institute of Technical Assistance and Rural Extension. 


\section{References}

ALVIM, M. J.; VERNEQUE, R. D. S.; VILELA, D.; CÓSER, A. C.; BOTREL, M. D. A.; REZENDE, G. M. Estratégia de fornecimento de concentrado para vacas da raça Holandesa em pastagem de coast-cross. Pesquisa Agropecuária Brasileira, Brasília, v. 34, n. 9, p. 17111720, 1999.

ARAGÃO, J. L.; PAES, M. S. Área biotecnologia. In: CONGRESSO BRASILEIRO DE MEDICINA VETERINARIA, 35., 2008, Gramado. Anais Eletrônicos... Gramado: CONBRAVET, 2008. Available at: <http://www.sovergs.com.br/conbravet2008/anais/cd/ lista_area_1 2.htm>. Accessed on: 25 Jun. 2014.

BÁNKUTI, F. I.; BÁNKUTI, S. M. S. Sistema agroindustrial do leite: cenário atual e perspectivas. In: SUL-LEITE SIMPÓSIO SOBRE SUSTENTABILIDADE DA PECUÁRIA LEITEIRA DA REGIÃO SUL DO BRASIL, 5., 2012, Maringá. Anais... Maringá: Nova Sthampa, 2012. p. 13-24.

BARGO, F.; MULLER, L. D.; KOLVER, E. S.; DELAHOY, J. E. Invited review: production and digestion of supplemented dairy cows on pasture. Journal of Dairy Science, Savoy, v. 86, n. 1, p. 1-42, 2003.

BUTOLO, J. E. Qualidade de ingredientes na alimentação animal. Colégio Brasileiro de Nutrição Animal (CBNA), 2 ed. Campinas. 430p. 2010.

CARDOSO, R. C.; PAIVA, P. C. A.; VILELA, D. Performance of holsteins cows in pasture of Cynodondactylon cv. Coast-crosssupplemented with concentrate. Ciência e Agrotecnologia, Lavras, v. 33, n. 6, p. 1663-1670, 2009.

CARVALHO, F. M.; RAMOS, E. O.; LOPES, M. A. Análise comparativa dos custos de produção de duas propriedades leiteiras, no município de Unaí-MG, no período de 2003 e 2004. Ciência e Agrotecnologia, Lavras, v. 33, p. 1705-1711, Dec. 2009. Número Especial. Available at: $<$ http://dx.doi.org/10.1590/S1413$70542009000700001>$. Accessed on: 10 jun. 2014.

CARVALHO, G. R. A Indústria de laticinios no Brasil: passado, presente e futuro. Juiz de Fora: Embrapa Gado de Leite, 2010. 11 p. (Circular Técnica, 102).

COlaVite, M.; GODOI, L. J.; ALVES, D. B. A produção de leite como alternativa para melhorar a renda de pequenos produtores rurais: considerações sobre a realidade observada no município de Corumbataí do SulPR. In: ENCONTRO DE PRODUÇÃO CIENTÍFICA E TECNOLÓGICA, 5., 2010, Campo Mourão. Anais... Campo Mourão: Fecilcam/Nupem, 2010. p. 1-10.
DAMASCENO, J. C.; BOUNDERMÜLLER FILHO, A.; RAMOS, C.; SANTOS, J. C.; SANTOS, G. T. O Papel do homem na gestão e controle de qualidade da produção de leite. In: SANTOS, G. T.; UHLIG, L.; BRANCO, A, F.; JOBIM, C. C.; DAMASCENO, J. C.; CECATO, U. (Org.). In: Inovação tecnológica na cadeia produtiva do leite e a sustentabilidade da pecuária leiteira. Maringá: Eduem, 2008. p. 125-135.

DERESZ, F.; MATOS, L. L.; MOZZER, O. L.; MARTINS, C. E.; AROEIRA, L. J. M.; VERNEQUE, R. S.; COSER, A. C. Milk yield of crossbred Holstein' Zebu cows supplemented or not with concentrate during the rainy season. Arquivo Brasileiro de Medicina Veterinária e Zootecnia, Belo Horizonte, v. 55, n. 3, p. 334-340, 2003.

FÁVERO, L. P.; BELFIORE, P.; SILVA, F. L.; CHAN, B. L. Análise de dados: modelagem multivariada para tomada de decisões. Rio de Janeiro: Elsevier, 2009. 646 p.

FODDY, W. Constructing questions for interviews and questionnaires: theory and practice in social research. Oxford: Cambridge University Press, 1994. 642 p.

FOOD AND AGRICULTURE ORGANIZATION OF THE UNITED NATIONS - FAO. FAOSTAT - The statistics division of FAO. 2013. Rome, Italy: FAO, 2013. Available at: $<$ http://faostat.fao.org $>$. Accessed on: 24 jan. 2014.

FAOSTAT - The statistics division of FAO. 2014. Rome, Italy: FAO, 2014. Available at: <http:// faostat.fao.org>. Accessed at: 18 may 2014.

GREGORI, C. D. Características do mercado do milho: uma importante participação brasileira. 2012. $65 \mathrm{f}$. Monografia (Graduação em Economia) - Universidade Regional do Noroeste do Estado do Rio Grande do Sul, Ijuí.

GUPTILL, A. Exploring the conventionalization of organic dairy: trends and counter-trends in Upstate New York. Agriculture and Human Values, Berlim. v. 26, n. 1-2, p. 29-42, 2009.

INFORMA ECONOMICS - AGRIANUAL. Anuário da agricultura brasileira 2014. São Paulo: MAXI Gráfica, 2014.

INFORMA ECONOMICS - ANUALPEC. Anuário da pecuária brasileira 2014. São Paulo: MAXI Gráfica, 2014.

INSTITUTO BRASILEIRO DE GEOGRAFIA E ESTATÍSTICA - IBGE. Censo agropecuário. Brasília, IBGE, 2006. Available at: <http://www.ibge.gov.br> Acessed on: 18 maio 2014. 
. Levantamento sistemático da produção agrícola. Brasília: IBGE, dec. 2012. Available at: <http://www. ibge.gov.br>. Accessed on: 23 jan. 2014.

INSTITUTO PARANAENSE DE DESENVOLVIMENTO ECONÔMICO E SOCIAL - IPARDES; INSTITUTO PARANAENSE DE ASSISTÊNCIA TÉCNICA E EXTENSÃO RURAL EMATER. Caracterização socioeconômica da atividade leiteira no Paraná. Curitiba: IPARDES, 2009.

LANA, R. P. Nutrição e alimentação animal: mitos e realidades. Viçosa: Editora UFV, 2007. v. 2, 344 p.

MARTINS, P. C.; CARNEIRO, A. V.; MARTINS, P. L. O.; LANA, M. S.; FERNANDES, G. E. O. Análise exploratória de sistemas de produção de leite de Minas Gerais. In: 51 Congresso da Sociedade Brasileira de Economia, Administração e Sociologia Rural - SOBER. 2013, Belém. Anais... Belém: UFPA, 2013. p. 22-43.

NASCIMENTO, R. E.; BOSCO, D. Comparação da produção de leite e de gordura e da duração da lactação entre cinco "graus de sangue" originados de cruzamentos entre Holandês e Gir em Minas Gerais. Arquivo Brasileiro de Medicina Veterinária e Zootecnia, Belo Horizonte, v. 53, n. 6, p. 708-713, 2001.

OLIVEIRA, A. S.; PEREIRA, D. H. Gestão econômica de sistemas de produção de bovinos leiteiros. In: SIMPÓSIO BRASILEIRO DE AGROPECUÁRIA SUSTENTÁVEL, 1., 2009, Viçosa. Anais... Viçosa: [s.n.], p. 106-133.

PAES, M. C. D. Aspectos físicos, químicos e tecnológicos do grão de milho. Sete Lagoas: Embrapa Milho e Sorgo, 2006. 6p. (Circular Técnica, 75).

PENROD, J.; PRESTON, D. B.; CAIN, R.; STARKS, M. T. A discussion of chain referral as a method of sampling hard-to-reach populations. Journal of Transcultural Nursing, London, v. 4, n. 2, p. 100-107, apr. 2003. Available at: <http://tcn.sagepub.com/content/14/2/100. full.pdf $>$. Accessed on: 03 jul. 2014.

REIS, R. P.; MEDEIROS, A. L.; MONTEIRO, L. A. Custos de produção da atividade leiteira na região sul de Minas Gerais. Organizações Rurais \& Agroindustriais, Lavras, v. 3, n. 2, p.10-21, 2001.

RENNÓ, F. P.; PEREIRA, J. C.; LEITE, C. A. M.; RODRIGUES, M. T.; CAMPOS, O. F. D.; FONSECA, D. M. D.; RENNÓ, L. N. Eficiência bioeconômica de estratégias de alimentação em sistemas de produção de leite: 1. Produção por animal e por área. Revista Brasileira de Zootecnia, Viçosa, MG, v. 37, n. 4, p. 743753, 2008.
ROEHSIG, L. Análise das estratégias de alimentação de vacas leiteiras a partir das práticas adotadas pelo produtor. 2006. Dissertação (Mestrado em Zootecnia) Universidade Estadual de Maringá, Maringá.

SCHLECHT, S.; SPILlER, A. A latent class cluster analysis of farmers' attitudes towards contract design in the dairy industry. Agribusiness, West Sussex, v. 28, n. 2, p. 121-134. 2012.

SECRETARIA DE ESTADO DA AGRICULTURA E ABASTECIMENTO DO PARANÁ/ DEPARTAMENTO DE ECONOMIARURAL - SEAB/DERAL. Comparativo de área, produção e produtividade no Paraná nas safras 11/12 - 12/13. Curitiba: SEAB, 2013. Available at: $<$ http://www.seab.pr.gov.br>. Acessed on: 23 jan. 2014.

SILVA, C. R.; LANA, R. D. P.; CAMPOS, J. D. S.; QUEIROZ, A. D.; LEÃO, M. I.; ABREU, D. D. Consumo e digestibilidade aparente dos nutrientes e desempenho de vacas leiteiras em pastejo com dietas com diversos níveis de concentrado e proteína bruta. Revista Brasileira de Zootecnia, Viçosa, MG, v. 38, n. 7, p. 1372-1380, 2009.

SILVA, H. A.; MORAES, A.; KOEHLER, H. S.; HACK, E.; GUIMARÃES, V. D. A.; CARVALHO, P. C. F. Análise da viabilidade econômica da produção de leite a pasto e com suplementos na região dos Campos GeraisParaná. Ciência Rural, Santa Maria, v. 38, n. 2, p. 445450, 2008.

SILVA, L. C. C.; BELOTI, V.; TAMANINI, R.; D’OVIDIO, L.; MATTOS, M. R.; ARRUDA, A. M. C. T.; PIRES, E. M. F. Rastreamento de fontes da contaminação microbiológica do leite cru durante a ordenha em propriedades leiteiras do Agreste Pernambucano. Semina: Ciências Agrárias, Londrina, v. 32, n. 1, p. 267276, 2011. Available at: <http://dx.doi.org/10.5433/16790359.2011v32n1p267>. Acessed on: 18 jun. 2014.

SIMÕES, A. R. P.; OLIVEIRA M. V. M. Vantagens comparativas do Brasil na produção de leite. In: CONGRESSO DA SOCIEDADE BRASILEIRA DE ECONOMIA, ADMINISTRAÇÃO E SOCIOLOGIA RURAL, 48., 2010, Campo Grande. Anais... Campo Grande: SOBER, 2010. p. 1-12.

SINDICATO NACIONAL DA INDÚSTRIA DE ALIMENTAÇÃO ANIMAL - SINDIRAÇÕES. Alimentação Animal. Cerqueira César: Boletim Informativo do Setor, mar. 2012. Available at: <http:// www.sindiracoes.org.br>. Acessed on: 19 jun. 2014.

VALADARES FILHO, S. C. Tabelas brasileiras de composição de alimentos para bovinos. Viçosa: UFV, 2006. 329 p. 
VARGAS, L. I. M.; PAULA LANA, R.; SILVA, J. C. P. M.; VELOSO, C. M.; QUEIROZ, A. C.; FONSECA, D. M.; RENNÓ, L. N. Desempenho de vacas mestiças em função de suplementação energética e proteica em dietas à base de cana-de-açúcar. Revista Brasileira de Agropecuária Sustentável, Viçosa, MG, v. 3, n. 1, p. 117127, jul. 2013.
YAMAZI, A. K.; MORAES, P. M.; VIÇOSA, G. N.; ORTOLANI, M. B. T.; NERO, L. A. Práticas de produção aplicadas no controle de contaminação microbiana na produção de leite cru. Bioscience Journal, Uberlândia, v. 26 , n. 4 , p. $610-618,2010$. Available at: <http:// www.seer.ufu.br/index.php/biosciencejournal/article/ viewArticle/7210>. Acessed on: 20 mar. 2014. 
